\title{
Rethinking Ethiopia's Bilateral Investment Treaties in light of Recent Developments in International Investment Arbitration
}

\footnotetext{
Martha Belete Hailu* and Tilahun Esmael Kassahun **

Abstract

International investment law is dynamic. As treaty practice and jurisprudence in the area constantly develop, global standards are always in the making. Rethinking Ethiopia's Bilateral Investment Treaties (BITs) is thus a natural response to evaluate the status of the country's obligations under the regime of global investment standards. This article briefly evaluates the concept of Most Favored Nation (MFN) treatment, in relation to the nature or purpose of MFN clauses and its interaction with dispute resolution provisions contained in BITs. In doing so, the article evaluates the different scenarios of 'treaty shopping' whereby an investor can possibly use BITs signed by Ethiopia and a state other than the investor's home state, to benefit from treaty obligations entered by Ethiopia with other partners. A review of Ethiopian BITs indicate that in almost all of the BITs, the MFN clause is phrased in general terms and leaves leverage to raise competing interpretations and creating a matrix of obligations thereby stretching the country's obligations under the respective agreements. This calls for revising the broad and incoherent application of the MFN standard contained in various BITs signed by Ethiopia with the aim to laying down a coherent investment treaty framework.
}

\section{Key words}

Most Favored Nation, Bilateral Investment Treaties, Investment Arbitration, Umbrella Clause, Standard of Treatment

DOI http://dx.doi.org/10.4314/mlr.v8i1.4

* PhD Candidate (Martin Luther University, Germany), LL.M (University of Western Cape), LL.B (Addis Ababa University), Lecturer Addis Ababa University, College of Law and Governance Studies, School of Law. Email: martha.b.hailu[at]gmail.com

** PhD Candidate, Bocconi University, Milan-Italy, LL.M (Business Law) Addis Ababa University, LL.M (International Economic Law and Policy, IELPO) University of Barcelona. The author teaches at Haramaya University College of Law and is currently on study leave. He can be reached at:

tilahun.kassahun[at]phd.unibocconi.it

The Authors are grateful for the comments they received from the internal and external reviewers. All errors remain ours. 


\section{Introduction}

International investment law is one of the most dynamic fields of international economic law. It is also one of the fields of international law discourse that is subject to continuous policy debate. This comes as no surprise considering the growing importance being given to protecting the flow of international investment and how deeply its contents are inserted in domestic policy making processes. The system is also influenced by the dynamics of globalization and global governance, and by various economic reforms resulting in investment disputes. In effect, the rules and principles of the regime are a flux. Treaty practice and jurisprudence in the area constantly develop and global standards are always in the making. Rethinking Ethiopia's Bilateral Investment Treaties (BITs) within this context is thus a natural response to evaluate the status of the country's obligations under the regime of evolving global investment standards.

However, it will be a disservice to attempt to evaluate the entire framework of BITs signed by Ethiopia in such short article. Rather, for the moment, the authors chose to examine one of the topical and hotly debated issues in the area; the dynamism in relation to the concept of Most Favored Nation (MFN) treatment. In particular the article addresses the nature and purpose of the clause and its interaction with dispute resolution provisions contained in BITs by taking recent developments in international investment dispute settlement. Generally the aim of this article is to show how recent application of MFN provision contained in basic treaty to benefit an investor from dispute settlement provisions contained in another comparator treaty is paving new grounds of application of the standard with the effect of stretching the country's obligations under the respective agreements.

The article thus attempts to elucidate the policy coherence pursued in this line. In making this evaluation, an attempt is made to review all BITs signed by Ethiopia and important international jurisprudence on the issue. In the meantime, it is also to be seen that case law and academic literature on the topic present constantly diverging stream of opinion. Thus, while the article attempts to be comprehensive in this regard, it does not claim to cover all ground.

The first section of the article provides a general observation on the development of BITs, by also putting the Ethiopian experience in context. Section Two discusses the nature, purpose and scope of the MFN clause in International Investment Agreements and also introduces the debate on its scope of application to and its interaction with dispute resolution provisions contained in BITs, which is the main subject matter of this article. Section Three deals with the types of MFN questions raised in the debate in the context of the rules contained under BITs sighed by Ethiopia. And finally, some observations of arbitral practice are highlighted in Section Four with a brief conclusion in the end. 


\section{General Observation on the Development of BITs}

Foreign investors are normally exposed to different and less known environment of the host country with its different culture and traditions, ideology, bureaucracy, legal system and political infrastructures, as well as a specific vulnerability to interference by the Host State. ${ }^{1}$ In order to mitigate the susceptibility of the foreign investor from the challenges that can be encountered in an unknown and unfamiliar system, certain mechanisms have been introduced through time. These mechanisms include diplomatic protection by the home state of the investor, the obligation under customary international law of host states to respect foreign investment, observation of the legal restrictions regarding procedures and compensation upon expropriation, arbitration of investment disputes as provided in multilateral and bilateral investment treaties, in national investment laws, and in the investment agreement of parties as well as enforcement procedures before state courts. ${ }^{2}$ Investment contracts that are signed between the investor and an entity of the host state also extend protection to the foreign investor.

Regarding the level of acceptability of some of these measures by the foreign investors, using Host state courts is not acceptable to many investors as relying on host country law alone will subject foreign investment capital to various risks. One risk is the danger that Host countries may easily change the law after an investment is made, and host government officials responsible for applying the local law may not always act impartially toward foreign investors and their enterprises. ${ }^{3}$ The protection given by customary international law is also seen as being not sufficient by foreign investors. 'Not only did customary international law contain no generally accepted rules on the subject, it also lacked a binding mechanism to resolve investment disputes." 4 Customary international law mainly dwells on the right of the host state to regulate the investment in its territory. As far as the right of investors is concerned, what has gained wide recognition as part of customary international law is the principle which requires host states to respect the property of citizens of other states, at least to the extent that the expropriating state has a duty to compensate the foreign owner. ${ }^{5}$

${ }^{1}$ Norbert Horn (2004), Arbitration and the Protection of Foreign Investment: Concepts and Means, in Norbert Horn and Stefan Kroll, (eds), Arbitrating Foreign Investment Disputes, (Kluwer Law International, The Netherlands), p 7.

${ }^{2}$ Ibid.

${ }^{3}$ Jeswald W. Salacuse (1990), BIT by BIT: The Growth of Bilateral Investment Treaties and Their Impact on Foreign Investment in Developing Countries, 24 International Lawyer, p. 659.

${ }^{4}$ Id., p. 660.

${ }^{5}$ Brownlie (1998), Principles of Public International Law, (Oxford University Press, Oxford, $5^{\text {th }}$ ed.), p. 535 . 
Moreover, there has been absence of a rapid development of international law to meet the needs of foreign investment. ${ }^{6}$

The other alternative resorted to by many states for protecting and promoting foreign investment is a bilateral investment treaty (BIT). BITs aim at protecting and promoting foreign investment between the contracting States Parties by granting a number of rights to foreign investors. ${ }^{7}$ The development of BITs began in the $18^{\text {th }}$ century with the signing of treaties of friendship, navigation and commerce (FNC). The signing of the Treaty of Amity and Commerce of 1782 between France and the United States ${ }^{8}$ marked the start of bilateral trade relations. The primary concern of FNCs was trade relations as they were designed at a time when commerce was largely restricted to trading in goods by merchants and did not contemplate direct investment by corporations. ${ }^{9}$ The treaties also extend to military matters. When we look into investment protection by the treaties, the provisions mainly focused on the protection of property in the country of another party ${ }^{10}$ Alien treatment, including freedom of worship and travel within the host state, was also included in the FCN. ${ }^{11}$ The treaties of FCN were used by countries until modern bilateral investment treaties emerged since the beginning of the 1960s.

Following the signing of the first modern BIT between West Germany and Pakistan in 1959, the conclusion of BITs has been one of the most active areas of public international law making in the last decades. ${ }^{12}$ By the end of 2013, the total number of BITs signed reached 2,857 while the number of other International Investment Agreements (IIAs) reached 339. ${ }^{13}$ The fact that these bilateral investment treaties can be negotiated in such a manner to suit the mutual interests of the parties ${ }^{14}$ and the absence of a comprehensive multilateral agreement on the area contributed to the popularity of the BITs.

6 M. Sornarajah (2010) The International Law on Foreign Investment, (Oxford University Press, Oxford, $3^{\text {rd }}$ ed), p. 184.

7 Stephan W. Schill (2009), Multilateralizing Investment Treaties through MostFavored-Nation Clauses, 27 Berkley Journal of International Law 2, p. 498.

${ }^{8}$ Alireza Falsafi (2008-2009), Regional Trade and Investment Agreements: Liberalizing Investment in a Preferential Climate, 36 Syracuse Journal of International Law and Commerce, pp. 45-46.

${ }^{9}$ Sornarajah, supra note 6, p. 209.

${ }^{10}$ Falsafi, supra note 8, p. 46.

${ }^{11}$ Sornarajah supra note 6, p. 210.

12 Salacuse, supra note 3, p 655.

${ }^{13}$ UNCTAD (2013), World Investment Report 2013: Global Value Chains: Investment and Trade for Development, (United Nations Publication, Geneva), p 101.

${ }^{14}$ Sornarajah, supra note 6, p. 183. 
One of the issues raised in connection with the proliferation of BITs is the effect of these BITs on the flow of Foreign Direct Investment (FDI) to the signatory countries, especially developing countries. It has been said that BITs boost the confidence of investors which in turn will increase the flow of FDI to host states. This is so as BITs guarantee certain rights of foreign investors which will encourage the foreign investors to invest in that country. ${ }^{15}$ These guarantees are believed to be credible as they provide an important procedural guarantee which allows investors to have the enforceable right to unilaterally initiate binding international arbitration against the host state that breaches its substantive promises of favorable treatment. ${ }^{16}$ And again, States with a record of nationalization see such treaties as cure for their past deeds. ${ }^{17}$

There are, however, also claims which shed doubt on this effect of BITs on Foreign Direct Investment (FDI). Authors like Sornarajah argue that it is empirically untestable whether states will receive more investments if they conclude such treaties. ${ }^{18}$ Salacuse and Sullivan also hold a similar view and attribute increase in flow of FDI to local political and economic conditions and government policies than BITs. ${ }^{19}$ Attributing increase in flow of FDI to BITs implies that the investors are aware and take into account the presence or absence of such treaties at the pre-investment stage, which in most cases is not true as many potential investors have little awareness or appreciation of specific BITs. ${ }^{20}$ And again it is wrong to assume that BITs are necessary to resolve the problem of credible commitment as investors have, for a long time, preferred to secure their interests through investment contracts which provide deal-specific promise that are more detailed and precise than the one-size-fits-all promise provided in BITs. $^{21}$

Whatever the effect of these treaties on FDI, the uncontested fact is that many developing countries signed them with developed as well as other developing countries. Ethiopia is no exception. In an effort to attract foreign investment, the government of Ethiopia has signed BITs with developed, as well

${ }^{15}$ Salacuse, supra note 3, p. 673.

${ }^{16}$ Jason Webb Yackee (October 2007), Do BITs Really Work? Revisiting the Empirical Link between Investment Treaties and Foreign Direct Investment, University of Wisconsin Law School Legal Studies Research Paper Series, Paper No. 1054, p 4.

${ }^{17}$ Sornarajah, supra note 6, p. 187.

${ }^{18}$ Ibid.

${ }^{19}$ Jeswald W. Salacuse and Nicholas P. Sullivan (2005), Do BITs Really Work?: An Evaluation of Bilateral Investment Treaties and Their Grand Bargain, 46 Harvard International Law Journal, p. 96.

${ }^{20}$ Yackee, supra note 16, p. 5.

${ }^{21}$ Id., p. 6. 
as developing countries. By the end of 2012, the country had signed 29 BITs. ${ }^{22}$ Out of the top ten countries which were the main sources of FDI to Ethiopia in 2011/2012 23 , Ethiopia has signed BITs with eight, namely Turkey, India, the Netherlands, United Kingdom, Sudan, China, Germany and Italy. The remaining two countries, the United States (US) and Qatar, are among the main sources of FDI even if they have not signed BITs with Ethiopia.

The structure of all BITs exhibits a striking similarity. They all contain a preambular statement which reiterates the aim of the treaty as the reciprocal encouragement and protection of investment. A definitional section which identifies the types of property protected is also included. The standard of treatment of the investor or the investment or both, standard of compensation as well as procedure for settlement of disputes also comprises part of the BITs. These standard contents in all the BITs are similar, but the wordings in which the statements are crafted have variation. It is this variation in the statements contained in the different BITs signed by a single country which at times leads to controversies. The focus of this article is on two aspects of these BITS: standard of treatment, particularly the Most Favored Nation Clause (MFN) and its interaction with dispute settlement provisions of the BIT.

\section{MFN Clauses in International Investment Agreements: Nature, Purpose and Scope}

The Most Favored Nation (MFN) clauses in international agreements entail an obligation of non discrimination on their signatories. Under these clauses, the signatories of a treaty agree to accord each other the same treatment they grant to any other nation. MFN treatment is "such treatment accorded by the granting state to the beneficiary state, or to persons or things in a determined relationship with that state, not less favorable than treatment extended by the granting state to a third state, or to persons or things in the same relationship as that third state." 24

It is believed that the first written MFN clause was contained in a treaty dated 8 November 1226, under which Emperor Frederick II conceded to the city

${ }^{22}$ UNCTAD, supra note 13, p. 231.

${ }^{23}$ Ethiopian Business Review, Top ten FDI Sources in Ethiopia in 2011/2012, (2013), available at http://www.ethiopianbusinessreview.com/index.php/statistics/item/88top-10-fdi-sources-in-ethiopia-in-2011-12.

${ }^{24}$ Alejandro Faya Rodriguez (2008), The Most Favored Nation Treatment Clause in International Investment Agreements: A tool for Treaty Shopping?, 25 Journal of International Arbitration 1, p. 90. 
of Marseilles the privileges previously granted to citizens of Pisa and Genoa. ${ }^{25}$ The origin of the modern MFN clauses can be traced back to the $15^{\text {th }}$ century, but they became common features of many friendship, commerce and navigation treaties during the $18^{\text {th }}$ and $19^{\text {th }}$ centuries. ${ }^{26}$ These early clauses were conditional as the benefits granted by one state were dependent on the granting of the same concessions by the beneficiary state. ${ }^{27}$

This trend was however changed with the adoption of the unconditional MFN obligation under the General Agreement on Tariff and Trade (GATT) in 1947. Even now, the unconditional MFN clause is the pillar of the World Trading System as its application extends beyond the original coverage of trade in goods to include trade in services and trade related aspects of intellectual property rights. (Article 2 of GATS and article 4 of TRIPS agreements). The MFN clause was also contained in the first BIT concluded between Germany and Pakistan in $1959 .{ }^{28}$ Subsequently concluded BITs and other International Investment Agreements (IIAs) also contained the clause to ensure that there is no discrimination among investors and investments, regardless of their origin. Their application may be limited to pre-establishment or may also include postestablishment activities.

The operation of MFN clauses in international law presupposes a relationship of at least three States: State A (the granting State) enters into an obligation visà-vis State $\mathrm{B}$ (the beneficiary State) to extend rights and benefits granted in a specific context to any third State $\mathrm{C}$. The consequence of the MFN clause in the treaty between A and B (basic treaty) is that State B can invoke and rely on all benefits State A grants vis-à-vis State C (in the comparator treaty) as long as the granted benefit is within the scope of application of the MFN clause in the relationship between $\mathrm{A}$ and $\mathrm{B} .^{29}$

Some of the major characteristics of MFN clauses include its relative nature and the fact that it covers both de jure and de facto discrimination based on nationality. ${ }^{30}$ Its relative nature is explained by the fact that a comparison has to

${ }^{25}$ Chris Newmark and Edward Poulton (January 2005), Most Favored Clause: Is the Siemens V Argentina Decision the High-Water Mark?, 20 Mealy's International Arbitration Report 1, p. 39.

${ }^{26}$ UNCTAD (2010), Most Favoured Nation Treatment: UNCTAD Series on Issues in International Investment Agreements I, (United Nations Publication, Geneva), p 9 see also Jurgen Kurtz (December 2004), The MFN Standard and Foreign Investment: an Uneasy Fit?, 5 Journal of World Investment and Trade 6, p. 863.

${ }^{27}$ Id., p. 10.

${ }^{28}$ Id., p 12.

29 Stephan Schill (2009), The Multilateralization of International Investment Law, (Cambridge University Press), p. 126.

${ }^{30}$ Rordiguez, supra note 24, p. 92. 
be made between two foreign investors or investments to determine existence of discrimination. As far as the second characteristic is concerned, it relates to the prohibition of discrimination on the basis of nationality, suggesting the possibility of discrimination on other objective grounds. Moreover, the principle of MFN applies where like circumstances or conditions exist, relieving the contracting parties from treating investors equally in different objective situations. $^{31}$ The other very important characteristic is the fact that the MFN clause is governed by the Ejusdem Generis principle. This principle requires that the MFN obligation applies to issues belonging to the same subject matter or the same category of subjects to which the clause relates. ${ }^{32}$ In International Investment Agreements, the subject matter is investment while the subjects are the investors. Hence, a beneficiary investor may invoke a benefit via the MFN treatment only in regards to the benefits granted to investors and investments of third state.

These MFN clauses in International Investment Agreements serve various purposes, one of which is "giving investors a guarantee against certain forms of discrimination by host countries, and establishing equality of competitive opportunities between investors from different foreign countries." 33 Their inclusion in BITs will put investors from different foreign countries on equal playing field. MFN clauses also protect the value of concessions made between the contracting parties to the basic treaty. It upholds the bargain that States struck by preventing each of them from hollowing out the content of the basic treaty by granting more favorable protection to a third State and thus making investments from the original treaty partner comparably less attractive. ${ }^{34}$

The other important function of an MFN clause is stabilizing expectations over time so as to reassure investors about making long term investments. ${ }^{35}$ With the MFN clauses, the investors will be assured that they will not be driven out of business due to grant of more favorable conditions for competitor investor in the future. Their existence ensures that whatever favorable condition is granted to the latter investor, will also be available for the previous ones. MFN treatment also has broader implications for the structure of international relations in implementing equal treatment among nations as such clause prevents states from forming economic alliances to the detriment and to the

${ }^{31}$ Ibid.

${ }^{32}$ UNCTAD, supra note 26, p. 24.

${ }^{33}$ UNCTAD (1999), Most Favoured Nation Treatment: UNCTAD Series on Issues in International Investment Agreements, (United Nations Publication, Geneva), p 1.

${ }^{34}$ Schill, supra note 29, p. 128.

${ }^{35}$ Scott Vesel (2007), Clearing a Path Through a Tangled Jurisprudence: Most Favored Nation Clauses and Dispute Settlement Provisions in Bilateral Investment Treaties, 32 Yale Journal of International Law, p. 142. 
exclusion of other States. ${ }^{36}$ As a result, the interest of smaller States will be protected against the influence of powerful States.

MFN clauses also have a purpose beyond governing investor-state relations. MFN clauses multilateralize the bilateral inter-state treaty relationship and harmonize the protection of foreign investment in a specific host state. ${ }^{37}$ This is so as the application of the MFN clause in the basic treaty entails the importing of more favorable treatments from the comparator treaty to benefit the investor from the beneficiary country. That is, the comparator treaty is incorporated by reference into the relationship between the state parties to the basic treaty without any additional act of transformation. ${ }^{38}$

This last purpose of MFN clauses gives rise to a debate on its scope in relation to its interaction with dispute resolution provisions contained in BITs. International tribunals are divided on how to reconcile a BIT's specific dispute resolution mechanism with an MFN clause which allows the investor to invoke a more favorable dispute settlement arrangement incorporated in a comparator treaty. This division between and among the international tribunals on the issue is partly due to the variation in the way in which the clauses are crafted in the different BITs.

In most investment treaties, the MFN clause is more general in its wording and leaves considerable scope to argue competing interpretations and it is not clear whether the MFN treatment they embrace includes only substantive rules or extends to dispute settlement as well. ${ }^{39}$ These BITs simply prohibit both contracting parties from according to investments of nationals of the other contracting party a less favorable treatment than that accorded to their own nationals or nationals of third states. ${ }^{40}$ Article 3(2) of the BIT between Ethiopia and the Kingdom of the Netherlands can be an example in this regard. The treaty provides:

Each Contracting Party shall accord to such investments treatment which in any case shall not be less favourable than that accorded either to

${ }^{36}$ Schill, supra note 29, p. 128.

${ }^{37}$ Schill, supra note 7, p 504. Rodriguez, however, argues that the purpose of MFN clause is to guarantee equality with respect to competitive conditions and not to contribute to harmonizing the procedural and substantive rights of IIAs. See Rodriguez supra note 24, p 100.

${ }^{38}$ Schill supra note 7, p. 507.

39 Dana H Freyer and David Herlihy (2005), Most Favored Nation Treatment and Dispute Settlement in Investment Arbitration: Just How "Favored" is "Most Favored"?, 20 Foreign Investment Law Journal 1, p. 60.

40 See also Julie A. Maupin (2011), MFN-Based Jurisdiction In Investor-State Arbitration: Is There Any hope For A consistent approach?, 14 Journal of International Economic Law 1, p. 165. 
investment of its own nationals or to investments of nationals of any third State, whichever is more favourable to the national concerned.

A similar provision is found in the BIT between Ethiopia and Finland. This type of clause is a general MFN provision as it is not restricted in its scope to any particular part of the treaty containing it. ${ }^{41}$ In some BITs, those general types of MFN clauses also provide that the most favored nation treatment to be enjoyed by the investors will be 'as regards their management, maintenance, use, enjoyment, or disposal of their investment. ${ }^{42}$ Article 4(2) of the Kuwait-Ethiopia ${ }^{43}$ BITs can be an example. The article states:

Each Contracting State shall accord investors of the other Contracting States, as regards any activity carried on in connection with their investments including, management, maintenance, use, enjoyment, disposal or compensation of such investments, treatment not less favorable than that which it accords to its own investors or to investors of any third state, whichever is the most favorable

The BITs Ethiopia signed with Germany ${ }^{44}$, Equatorial Guinea ${ }^{45}$, the State of Israel $^{46}$, Kingdom of Spain ${ }^{47}$, Republic of Tunisia ${ }^{48}$, People's Democratic Republic of Algeria ${ }^{49}$, Islamic Republic of $\operatorname{Iran}^{50}$, and the Republic of Austria ${ }^{51}$

${ }^{41}$ OECD (2005), International Investment Law: A Changing Landscape- A Companion Volume to International Investment Perspectives, p. 130.

${ }^{42}$ See also Maupin, supra note 40, p. 165.

43 Agreement between the Federal Democratic Republic of Ethiopia and the State of Kuwait for the encouragement and reciprocal protection of investment, signed on 14 September 1996, entered in to force on 12 November 1998.

44 Treaty between the Federal Republic of Germany and the Federal Democratic Republic of Ethiopia Concerning the Encouragement and Reciprocal Protection of Investments, signed on 19 January 2004 entered into force on 4 May 2006.

45 Agreement between the Republic of Equatorial Guinea and the Government of the Federal Democratic Republic of Ethiopia on the Reciprocal Promotion and Protection of Investment signed on 11 June 2009.

${ }^{46}$ Agreement between the Government of the Federal Democratic Republic of Ethiopia and the Government of the State of Israel for the Reciprocal Promotion and Protection of Investment signed on 26 November 2003, entered into force 22 March 2004.

${ }^{47}$ Agreement between the Federal Democratic Republic of Ethiopia and the Kingdom of Spain on the Promotion and Reciprocal Protection of Investments, Signed on 17 March 2009.

${ }^{48}$ Agreement between the Government of the Federal Democratic Republic of Ethiopia and the Government of the Republic of Tunisia for the Promotion and Protection of Investment signed on 14 December 2000, entered into force 2 October 2004.

49 Agreement between the Government of the Federal Democratic Republic of Ethiopia and the Government of the People's Democratic Republic of Algeria on the 
contain similarly worded provisions. Such clauses are general in that they do not define the precise meaning of the word 'treatment'; nor do they specify the scope of the MFN obligation. ${ }^{52}$ It is also not clear if the favorable treatment for the 'management, maintenance, use, enjoyment or disposal of the investment' would include dispute resolution provisions. In this regard, different tribunals have reached at different conclusions as to whether dispute resolution provisions may be considered to be a normal part of the 'management, use, enjoyment or disposal' of investment. ${ }^{53}$

Some BITs are drafted broadly and they provide either explicitly or implicitly that the MFN clauses apply to dispute resolution provisions. Such clauses contain a sweeping language which indicates that the BIT's MFN commitment applies to 'all matters' covered in the treaty. ${ }^{54}$ For example, Article 4(1) of the BIT signed between Ethiopia and the Belgian-Luxembourg Economic Union ${ }^{55}$ reads:

In all matters relating to the treatment of investments, the investors of each Contracting Party shall enjoy national treatment or most-favourednation treatment in the territory of the other Contracting Party. ${ }^{56}$

Although some other BITs do not have such phrase as 'all matters' it would still be considered as broad since they specifically mention that the MFN

Reciprocal Promotion and Protection of Investments, Signed on 4 June 2002, entered into force 1 November 2005.

50 Agreement of Reciprocal Promotion and Protection of Investments Between the Government of the Federal Democratic Republic of Ethiopia and the Government of the Islamic Republic of Iran, Signed on 21 October 2003, entered into force 15 December 2005.

${ }^{51}$ Agreement between the Federal Democratic Republic of Ethiopia and the Republic of Austria on the Promotion and Protection of Investment signed on 12 November 2004 entered into force 1 November 2005.

${ }_{53}^{52}$ Maupin, supra note 40, p. 165.

${ }^{53}$ Ibid.

${ }_{55}^{54}$ Id., p. 163.

55 Agreement between the Belgian-Luxembourg Economic Union and the Federal Democratic Republic of Ethiopia on the Promotion and Protection of Investment signed on 26 October 2006.

56 Agreement between the Belgian Luxembourg Economic Union and the Federal Democratic Republic of Ethiopia on the Reciprocal Promotion and Protection of Investments, signed on 26 October 2006, article 4(1). 
commitment extends to dispute resolution provisions as well. Article 3 of the UK-Ethiopia ${ }^{57}$ BIT, for instance, provides:

1. Neither Contracting Party shall in its territory subject investments or returns of nationals or companies of the other Contracting Party to treatment less favourable than that which it accords to investments or returns of its own nationals or companies or to investments or returns of nationals or companies of any third State.

2. Neither Contracting Party shall in its territory subject nationals or companies of the other Contracting Party, as regards their management, maintenance, use, enjoyment or disposal of their investments, to treatment less favourable than that which it accords to its own nationals or companies or to nationals or companies of any third State.

3. Except provided otherwise in this Agreement and for the avoidance of doubt, it is confirmed that the treatment provided for in paragraphs (1) and (2) above shall apply to the provisions of Articles 1 to 10 of this Agreement.

Article 8 of the agreement deals with dispute settlement between an investor and the host state. Thus, the provision contains a broad MFN clause as it is applicable with regard to the settlement of investor-state investment disputes.

There is also a possibility for the granting state and the beneficiary state to draft the MFN clause narrowly and limit in the basic treaty the extent of the favors that can be claimed by the beneficiary. ${ }^{58}$ This narrowly drafted MFN clause in the basic treaty will exclude dispute settlement provision/s from the scope of the MFN clause. And again, the scope of the MFN clause might be narrowed down subsequent to entry into force of the BIT through exchange of interpretative note by the signatories or inclusion of 'vanishing footnote'. Retrospective interpretation of the MFN clause in a restrictive manner through exchange of note was resorted to by Argentina and Panama in which they stated that the MFN clause will not be applicable to dispute resolution and that 'this has always been their intention'. 59 In the Central America (Dominican Republic-United States) Free Trade Agreement (CAFTA), the parties to the

57 Agreement between the government of the United Kingdom of Great Britain and Northern Ireland and the Federal Democratic Republic of Ethiopia for the Promotion and protection of investment, signed on 19 November 2009.

${ }^{58}$ OECD, supra note 41, p. 142.

${ }^{59}$ Rudolf Dolzer and Christoph Schreuer (2008), Principles of International Investment Law, (Oxford University Press), pp. 187-188. 
agreement inserted a footnote to the negotiating history limiting the scope of the MFN clause. ${ }^{60}$

Though the classical approach in drafting MFN clauses is the one which combines MFN treatment with national treatment, ${ }^{61}$ there are also some BITs which tie the MFN treatment to Fair and Equitable treatment (FET) ${ }^{62}$ Those BITs which tie MFN to FET provide in one paragraph the requirement to extend FET to the investor from the other contracting party and add another paragraph which specifies that the FET shall not be less favorable than that provided to the investors from a third state. Article 3 of the BIT between Ethiopia and China ${ }^{63}$ provides:

1. Investments and activities associated with investments of investors of either Contracting Party shall be accorded fair and equitable treatment and shall enjoy protection in the territory of the other Contracting Party

2. The treatment and protection referred to in paragraph 1 of this article shall not be less favorable than that accorded to investments and activities associated with such investments of investors of any third state.

The BITs Ethiopia signed with Russia ${ }^{64}$ and Libya Arab Jamahiriya ${ }^{65}$ contain similarly worded provisions. These types of clauses present confusion as they tie

${ }^{60}$ Maupin supra note 40, p 167. The added foot note reads as:

'The MFN Treatment article of this Agreement is expressly limited in its scope to matters 'with respect to the establishment, acquisition, expansion, management, conduct, operation and sale or other disposition of investment.' The parties share the understanding and intent that this clause does not encompass international dispute resolution mechanisms such as those contained in Section $\mathrm{C}$ of this chapter, and therefore could not reasonable lead to a conclusion similar to that of the Maffezini case. See Id., note 43 and Andreas R. Ziegler, (2010), 'The Nascent International Law on the Most Favored Nation (MFN) Clauses in Bilateral Investment Treaties (BITs), 1 European Yearbook of International Economic Law, p 93.

${ }^{61}$ Dolzer and Schreuer, supra note 59, p. 187.

${ }^{62}$ The Fair and Equitable Treatment (FET) is an objective standard of treatment. Though the concept lacks precise definition, the elements of the content of the standard as fleshed out by arbitral tribunals include transparency and protection of investor's legitimate expectation, prohibition of manifest arbitrariness, protection against denial of justice and due process, freedom from coercion and harassment and the requirement of good faith on the part of the host state.

${ }^{63}$ Agreement between the government of the Federal Democratic Republic of Ethiopia and the government of the People's Republic of China concerning the encouragement and reciprocal protection of investment, signed on 11 May 1998 entered in to force on 1 May 2000.

${ }^{64}$ Agreement between the government of the Federal Democratic Republic of Ethiopia and the Government of the Russian Federation on the Promotion and Reciprocal 
the relative standard of MFN with the objective standard of FET and it is not clear in what way the two are supposed to interact. ${ }^{66}$

\section{Types of MFN Questions}

The wording used in the drafting of MFN clauses varies from one BIT to another. While, the interpretation of the MFN clause by international jurisprudence is not a recent development, most of the international investment dispute settlement practice addressed the MFN standard with regard to substantive rights. ${ }^{67}$ However, more recent investment case law also dealt with the question whether the MFN standard should apply to dispute settlement procedures. $^{68}$

There are generally three scenarios in which an MFN clause within a BIT may be invoked. Under the first scenario, the beneficiary of an MFN clause invokes the MFN clause in order to obtain the benefit of some more favorable substantive treatment that has been granted by the host state to a third state's investment via the host state's domestic legislation or regulation. ${ }^{69}$ Here the MFN clause of a BIT is invoked to import the more favorable treatment which is granted to another investor under the domestic legislation of the host state. In the second scenario, the claimant invokes the basic treaty's MFN clause in order to import into the treaty the more favorable substantive protections that have been granted by the host state to a third state's investor by the comparator treaty. ${ }^{70}$ Here the investor is relying on the MFN clause of the basic treaty to import a favorable treatment from the comparator treaty to the basic treaty. Today, several investment tribunals have accepted the possibility of importing more favorable substantive protection from a comparator treaty to the basic

Protection of Investments, signed on 10 February 2000, entered into force 6 June 2000.

${ }^{65}$ Agreement between the Government of the Federal Democratic Republic of Ethiopia and the Great Socialist People's Libyan Arab Jamahiriya concerning the Encouragement and Reciprocal Protection of Investments, signed on 27 January 2004, entered into force 25 June 2004.

${ }^{66}$ Maupin, supra note 40, p. 166.

${ }^{67}$ Most Favoured Nation Treatment Application in International Investment Arbitration A Study on Conflicting Precedence in International Dispute Settlement Procedure, (2001), University of Oslo, p 4, available at:

$<$ https://www.duo.uio.no/bitstream/handle/10852/22714/Master_thesis.pdf?sequence=1>

${ }^{68}$ UNCTAD (2007), Investor-State Dispute Settlement and Impact on Investment Rule Making, (United Nations Publication, Geneva), p. 52.

${ }^{69}$ Maupin, supra note 40, p. 159.

${ }^{70}$ Ibid. 
treaty. ${ }^{71}$ For instance, in the first known investment treaty arbitration, Asian Agricultural Products versus Sri Lanka, the Tribunal accepted the principle that an investor covered by the basic treaty could rely on more favorable substantive conditions granted under another BIT of the host State. ${ }^{72}$ The tribunals in Pope \& Talbot versus Canada and MTD versus Chile cases are few of the other tribunals which allowed the incorporation of substantive rights from third country BITs through MFN clause to the basic treaty. ${ }^{73}$

The third scenario in which an MFN clause may be invoked relates to the importation of more favourable dispute resolution provisions from a comparator treaty to the basic treaty. There are potentially four sets of questions that may arise in investor-state arbitration in this regard.

\subsection{Changes to Arbitral Procedure}

The first set of 'MFN' claims under investment dispute settlement practice involves circumstances by which a claimant investor will attempt to override procedural obstacles under the basic treaty using the BITs MFN clause to use more preferable procedural terms that exist in another comparator BIT. ${ }^{74}$ The procedural hurdle that the claimant wants to avoid could relate to the use of domestic court as forum for settlement of the dispute or longer consultation period before resorting to arbitration or adjudication. Much dispute settlement jurisprudence has been set in this regard. The first of these issues was decided following the landmark arbitration in Maffezini versus Spain, ${ }^{75}$ although this tribunal was actually not the first to face this issue. ${ }^{76}$ In Maffezini, the Argentine

${ }^{71}$ Emmanuel Gaillard, (2005), Establishing Jurisdiction through A Most-FavoredNation Clause, International Arbitration Law, 233 New York Law Journal 105.

72 Asian Agricultural Products v. Sri Lanka, Final Award, June 27, 1990, Para 54, However, the investor in this case did not prevail on the more favorable conditions because the investor could not show that the Swiss-Sri Lankan BIT provided for a stricter liability standard of the host State compared with the British-Sri Lankan BIT. See Schill supra note 29, p. 140.

${ }^{73}$ Nonetheless, there are also cases in which the importation of favorable substantive rights from comparator treaty has been controversial. For more on this please see UNCTAD supra note 26.

${ }^{74}$ Maupin, supra note 40, p. 168.

${ }^{75}$ Emilio Agustín Maffezini and the Kingdom Of Spain, Case No. ARB/97/7, Decision of The Tribunal On Objections To Jurisdiction, 2000.

76 This question was extensively discussed in the Anglo-Iranian Oil Company Case, where the International Court of Justice determined that the basic treaty upon which the Claimant could rely was that "containing the most-favored-nation clause". International Court of Justice, Reports, 1952, at 109. Also see the Case concerning the rights of nationals of the United States of America in Morocco. International Court of Justice, Reports, 1952, p. 191. 
investor in Spain was allowed to use a more beneficial time requirement in the arbitration process found in the Chile-Spain BIT (as opposed to the ArgentinaSpain BIT under which the claim was filed). The tribunal accepted application of the MFN principle, subject to the limitation that it did not override public policy considerations of the parties to the negotiations. ${ }^{77}$ The tribunal stated:

56 . ... if a third party treaty contains provisions for the settlement of disputes that are more favorable to the protection of the investor's rights and interests than those in the basic treaty, such provisions may be extended to the beneficiary of the most favored nation clause as they are fully compatible with the ejusdem generis principle. Of course, the third-party treaty has to relate to the same subject matter as the basic treaty, be it the protection of foreign investments or the promotion of trade, since the dispute settlement provisions will operate in the context of these matters; otherwise there would be a contravention of that principle. This operation of the most favored nation clause does, however, have some important limits arising from public policy considerations $[\ldots]^{78}$

Similarly, subsequent investment tribunals have been faced mostly with the question of whether MFN clauses allow an investor to rely on shorter waiting periods in third-country BITs or to do away with the requirement to pursue local remedies for a limited time before initiating investor-State arbitration. Accordingly, until today, arbitral jurisprudence has consistently accepted that investors may circumvent such 'admissibility-related' requirements by relying on more favorable provisions for investor-State dispute settlement under a comparator BIT. $^{79}$ In this respect, "MFN clauses have been held to multilateralize access to investment treaty arbitration." ${ }^{\circ 0}$ The issue has been "applied as one principle of international investment law that has been

${ }^{77}$ Maffezini v. Spain ARB/97/7, decision on Jurisdiction. Also see UNCTAD, (2005), Investor-State Disputes Arising From Investment Treaties: A Review, Series on International Investment Policies for Development, (United Nations Publication, Geneva).

${ }^{78}$ Id., Para 56.

${ }^{79}$ Perhaps the only exception in this regard is the arbitral ruling in Wintershall where the tribunal did not agree to the possibility of circumventing an 18 month cooling period before the investor could lodge claims under international arbitration. In reaching this conclusion the tribunal stated that "That the eighteen-month requirement of a proceeding in a local court constitutes a necessary preliminary step to an ICSID arbitration under the Argentina-Germany BIT is apparent from the text of Article 10 itself." And thus the state's consent must be explicit and cannot be inffereed. Wintershall Aktiengesellschaft v. Argentine Republic, ICSID Case No. ARB/04/14,( November 8, 2008).

${ }^{80}$ Schill, supra note 29 , p. 145. 
incorporated in the pertinent BIT and is independent of the exact wording of the MFN clause in question." 81

Accordingly, this issue brings three different scenarios of 'treaty shopping' to our attention whereby an investor can possibly use BITs signed by Ethiopia, other than the investor's home state, to benefit from treaty obligations entered by Ethiopia with other partners.

\section{a) Shorter consultation periods:}

The first cases that one can make out of the present circumstance of arbitral practice against the contents of BITs signed by Ethiopia involves the length of time periods which an investor has to wait for to challenge the state action under the established dispute settlement framework of the particular BIT. ${ }^{82}$ These issues involve a scenario where the basic treaty provides for particular conditions before an international arbitration proceeding can be initiated, for example, a cooling-off period varying from three to six months or sometimes the exhaustion of local remedies. Simply, the question is whether an MFN clause can be invoked to benefit from the more favorable conditions of a thirdparty treaty ${ }^{83}$

While almost all BITs signed by Ethiopia reviewed for the purpose of this article set a consultation time period of six months, ${ }^{84}$ the bilateral investment treaty signed by Ethiopia with UK, Finland and South Africa provide for a shorter, three months, waiting period of consultation before a dispute can be submitted either to national courts or international arbitration tribunal as the case may be. Article 8 of the UK-Ethiopia BIT reads as follows:

ARTICLE 8: Settlement of Disputes between an Investor and a Host State

Any dispute between a national or company of one Contracting Party and the other Contracting Party concerning an obligation of the latter under this Agreement in relation to an investment of the former which has not been amicably settled shall, after a period of three months from written notification of a claim, be submitted to the competent courts or administrative tribunals of the Contracting Party, to the dispute, or to

${ }^{81}$ Ibid.

${ }^{82}$ Most BITs often require that investors wait for a certain period of time, a 'cooling off' period of usually three or six months, before commencing arbitration. C. Ignacio Suarez Anzorena and William K. Perry (2010), Protecting Foreign Investments and Arbitration, In-House Defense Quarterly, p. 60.

${ }^{83}$ Gaillard, supra note 71.

${ }^{84}$ For instance see BIT between Germany and Ethiopia Article 11 sub 2; Ethiopia and Russian federation Art 8 sub 2; Ethiopia and Sudan Art 8 sub 2. 
international arbitration if the national or company concerned so wishes. ${ }^{85}$ [Emphasis added]

Even more so, the Ethio-Austria BIT provides for sixty days (two month) waiting period before a dispute can be submitted to the appropriate organs. Article 12(2) of the treaty provides that a dispute 'may be submitted for resolution [...] after 60 days from the date notice of intent to do so was provided to the Contracting Party, party to the dispute $[\ldots]^{86}$

Thus, one can see that few BITs signed by Ethiopia provide for a three month or less waiting period while virtually all BITs provide for a 6 month waiting periods of 'consultation'. Accordingly, it seems that investors from other BITs can base their claim under their basic treaty's MFN provisions to claim a more preferable (shorter waiting/consultation period) as included under the EthiopiaUK, South Africa, Finland or even more the Ethio-Austria BIT.

\section{b) Agreement of the State:}

Another interesting case to note is the scenario where the basic treaty contains a dispute settlement clause but no choice is given to the investor as regards the type of arbitration, notably institutional arbitration such as the International Center for Settlement of Investment Disputes (ICSID) ${ }^{87}$ Hence the difficult question would be whether the MFN clause can be invoked to seek the benefit of 'investor's-option' offered in a third-party treaty? ${ }^{88}$

The only instance in this regard under BITs signed by Ethiopia is the manner of submitting dispute claims to an international arbitration under the EthioDenmark BIT. ${ }^{89}$ Under this agreement ${ }^{90}$, despite a clear invocation by the terms

${ }_{86}^{85}$ Art 8 of the BIT between Ethiopia and UK.

${ }^{86}$ Paragraph 1(c) of article 12 deals with settlement of investment dispute using arbitration at ICSID or ICSID Additional Facility, sole arbitrator or ad hoc arbitral tribunal established under the Arbitration Rules of the United Nations Commission on International Trade Law ("UNCITRAL) or the International Chamber of Commerce, by a sole arbitrator or an ad hoc Tribunal under its Rules of Arbitration.

${ }^{87}$ It is the argument of the authors that the limitations defined by the Maffezini Tribunal don't cover this matter. The limitations set by that tribunal covered such "public policy considerations" as the exhaustion of local remedies, the stipulation of a forkin-the-road clause (i.e., an irreversible option offered to the investor between the courts of the host state and international arbitration), the provision of a particular arbitration forum such as ICSID, or the parties' agreement to have a highly institutionalized system of arbitration-such as NAFTA.

${ }_{88}^{88}$ Gaillard, supra note 71 .

89 Agreement between the Federal Democratic of Ethiopia and the Kingdom of Denmark Concerning the Promotion and Reciprocal Protection of Investments, signed on 24 April 2001 entered into force 21 August 2005.

${ }^{90}$ Also see the BIT between Ethiopia and South Africa, which provides: 
of the treaty that the investor can chose to submit its claim between the local courts of the host sate and an international arbitration tribunal, it seems that the agreement of the concerned parties is required to submit the case to any of arbitration panels listed under Art 9 Sub 2 lit a-c, thus at the same time limiting the investor's choice of forum.

Article 9: Settlement of disputes between a Contracting Party and an investor of the other Contracting Party

2. Where the dispute is referred to international arbitration, parties in the dispute may agree to refer the dispute either to:
a) the International Center for Settlement of Investment Disputes (ICSID) ...
b) the International Center for Settlement of Investment Disputes under the rules governing Additional Facility ...
c) an international ad hoc tribunal... [Emphasis added]

This seems to be a 'weak obligation' as the word 'may' does not constitute a strong obligation. But in any case, if one considers this to be an 'obstacle' for a Danish investor against submitting the case for international arbitration, it certainly brings an interesting thought with regard to what an arbitration panel would decide if a claim was brought to it without securing an agreement from its host counterpart, by merely basing its claim on an MFN provision which this basic treaty contains and thereby asking to benefit from other BITs signed by Ethiopia which do not require such type of prerequisites.

(2) Where the dispute is referred to international arbitration, the investor and the Party concerned in the dispute may agree to refer the dispute either to:

(a) The International Center for the Settlement of Investment Disputes (ICSID) established by the Convention on the Settlement of Investment Disputes between States and Nationals of Other States, opened for signature at Washington DC on 18 March 1965. As long as this requirement is not met, each Party agrees that the dispute may be settled under the rules governing the Additional Facility for the Administration of Proceedings by the Secretariat of ICSID; or

(b) an international arbitrator or ad hoc arbitration tribunal to be established by agreement between the Parties to the dispute.

(3) If after a period of three months from written notification of the investor's decision to refer the dispute to international arbitration there is no agreement on one of the alternative procedures referred to in sub-article (2), the dispute shall, at the written request of the investor concerned, be dealt with in terms of the procedure preferred by the investor. 


\section{c) 'Period of limitation':}

Finally under Austria-Ethiopia BIT there is a limitation against admissibility of a 5 year period of limitation which is not included in other BITs. Article 12(2) of the BIT states:

A dispute may be submitted for resolution pursuant to paragraph 1(c) of this Article after 60 days from the date notice of intent to do so was provided to the Contracting Party, party to the dispute, but not later than five years from the date the investor first acquired or should have acquired knowledge of the events which gave rise to the dispute.

Accordingly, an interesting question to bring to a hypothetical panel's attention is whether an Austrian investor can use the MFN provision in the AustriaEthiopia BIT and claim a more preferable treatment whereby his claims would not be barred by period of limitation as almost all BITs signed by Ethiopia do not provide such kind of 'obstacle'.

\section{2- Expansion of subject-matter-scope of arbitral clause}

These sorts of claims involve applications by an investor to broaden the limited subject matter coverage of the basic treaty by embedding more extensive subject matter coverage of a comparator BIT. This category comprises attempts to overcome the limited subject matter jurisdiction granted to a tribunal under a basic treaty's dispute resolution clause by importing, via MFN clause, the broader subject matter jurisdiction granted under a comparator treaty. ${ }^{91}$

The relevance of this issue would have been moot had the BITs signed by Ethiopia followed consistent approach while marking the scope of dispute settlement mechanisms and choice of dispute settlement institutions. But this is not the case. Among the 28 BITs reviewed for the purpose of this article, two appear to be distinct concerning this issue. In particular, review of the BIT signed between Ethiopia and China indicate that the reference to international arbitration panels is limited only in cases where the subject matter of dispute is the amount of compensation. Article 9(3) of the BIT states:

If a dispute involving the amount of compensation for expropriation cannot be settled within six months after resort to negotiations as specified in Paragraph 1 of this article, it may be submitted at the request of either party to an ad hoc arbitral tribunal or arbitration under the auspices of ICSID....

${ }^{91}$ Maupin, supra note 40, p. 170. 
An award on jurisdiction between RosInvest Co. UK Ltd vs. The Russian Federation ${ }^{92}$ has permitted an investor to avail itself of the most-favoured nation clause in the underlying BIT between the Soviet Union and the United Kingdom, ${ }^{93}$ in order to extend the tribunal's jurisdiction to issues of occurrence and validity of expropriation, which were not covered by the limited jurisdiction clause in the BIT. Through the applicable MFN clause, the tribunal based its jurisdiction on the broader jurisdiction clause in the BIT between Denmark and the Russian Federation. ${ }^{94}$ It was the first award which set a potential milestone for future jurisprudence which enables a tribunal to employthe MFN clause to extend its jurisdiction to categories of claims excluded by the jurisdiction clause of the applicable BIT as the interpretation of the MFN clause had previously been rejected in Plama Consortium Ltd v. Bulgaria, ${ }^{95}$ and Telenor Mobile Communications A.S. v. Republic of Hungary. ${ }^{96}$

Most recently, however, the Austrian Airlines versus Slovakia award has reiterated the latter position. ${ }^{97}$ In this award, the panel found that it has the mandate to interpret the provisions of the underlying BIT "neither restrictively nor expansively but rather objectively and in good faith" and thus while it is acceptable to rely on the MFN clause to benefit from certain advantageous dispute settlement clauses contained in other treaties it however rejected the possibility for an investor, by relying on the MFN clause, to seek to extend the arbitral jurisdiction of the panel to matters not covered under the agreement. According to the panel, "Taken in context, Article 3(1) is not a neutral MFN clause. The Contracting States have confined recourse to arbitration to clearly defined categories of disputes. This is particularly evident for expropriation claims. It is also clear for disputes over transfer obligations. Seen in interaction with the express limitations which the Treaty imposes on arbitration, the general

${ }^{92}$ RosInvestCo Uk Ltd. Vs The Russian Federation, Case No. Arbitration Award V 079/2005, Arbitration Institute of the Stockholm Chamber of Commerce, Award on Jurisdiction (October 2007).

93 Agreement between the Government of the United Kingdom of Great Britain and Northern Ireland and the Government of the Union of Soviet Socialist Republics for the Promotion and Reciprocal Protection of Investments (UK-Soviet BIT) signed in 1989.

94 UNCTAD, (2008), Latest Developments in Investor-State Dispute Settlement, International Investment Agreements MONITOR, No. 1.

${ }^{95}$ (ICSID Case No. ARB/03/24, 2005).

96 (ICSID Case No. ARB/04/15, 2006) Also See UNCTAD, supra note 86.

${ }^{97}$ Austrian Airlines v. The Slovak Republic, UNCITRAL, Finaly Award October 9, 2009. < http://www.italaw.com/sites/default/files/case-documents/ita0048_0.pdf > 
intent manifested in the MFN clause is insufficient to displace such limitations. ${ }^{98}$

Another reassurance for Ethiopia might be the fact that the tribunal in RosInvest case decided to expand its subject matter jurisdiction based on a general MFN clause of the BIT between Soviet Union and UK while the type of MFN clause in the Ethiopia-China BIT is tied to FET. It is worth noting that a similar approach is used in the BIT between Ethiopia and Libya.

Another possible way of extending the subject matter scope of a tribunal is by seeking to import 'Umbrella Clause' from the comparator treaty to the basic treaty. Umbrella clauses are clauses through which the contracting parties assume-as a matter of treaty law-additional substantive and/or procedural obligations with regard to undertakings contained in instruments extraneous to the treaty. ${ }^{99}$ According to Schill, umbrella clauses create a separate obligation under the investment treaty in question to observe obligations the host state has assumed in relation to foreign investors, in particular obligations under investorstate contracts. ${ }^{100}$ Hence, an investor that benefits from a BIT which contains an umbrella clause can assert violation of the treaty which entails international responsibility of the host state that failed to observe commitments entered under an investor-state contract. The question then would be whether an in investor can attempt to import an umbrella clause from a comparator treaty to the basic treaty relying on the MFN clause of the basic treaty.

In the case EDF International S.A. et.al versus Argentina ${ }^{101}$, the French claimant invoked the MFN clause contained in the BIT between Argentina and France in order to benefit from the protection of umbrella clauses found in the BIT between Argentina and Belgian Luxembourg Economic Union, and Argentina and Germany. ${ }^{102}$ The tribunal in the case concluded that the MFN clause permits recourse to the umbrella clauses of third country treaties as it

${ }^{98}$ Ibid, para 138. However also see the opinion of the dissenting arbitrator as he stated "Article 3(1\} of the Treaty, [MNF] according to Austrian investors treatment equal to that granted to investors under any third-State treaty of the Slovak Republic, covers both substantive and procedural treatment, including the consent to international arbitration given by Slovakia under any of its other BITs." Austrian Airlines v. The Slovak Republic, Separate Opinion of Charles N. Brower, p 2. http://www.italaw.com/sites/default/files/case-documents/ita0047_0.pdf, >

99 Tracisio Gazzini and Attila Tanzi (2013), Handle with Care: Umbrella Clauses and MFN Treatment in Investment Arbitration, 14 The Journal of World Investment and Trade, p. 985.

${ }^{100}$ Schill, supra note 29, p. 84.

${ }^{101}$ EDF International S.A, SAUR International S.A. and Leon Participaciones Argentinas S.A. V. Argentine Republic, ICSID ARB/03/23, Award, 11 June 2012.

${ }^{102}$ Gazzini and Tanzi, supra note 99, p. 981. 
accords investors anything other than those rights which fall within the limits of the subject matter of the clause. ${ }^{103}$ In another case, Salini vs. Jordan, the claimant attempted to import an umbrella clause from a comparator treaty in order to bring its contract-based claims before an investor-state tribunal, although the basic BIT specifically prohibited contract claims, deferring instead to the contractually selected forum. ${ }^{104}$ The Tribunal, however, declined the claim.

When we look into the BITs Ethiopia has signed, some of them contain umbrella clauses. One example is Article 8(2) of the Ethiopia-Germany BIT which states:

A Contracting Party shall adhere to any other obligation deriving from a written commitment undertaken by it in favor of an investor of the other Contracting Party with regard to an investment in its territory.

The BITs Ethiopia signed with Denmark and Kuwait also contain umbrella clauses, although the wording is different. ${ }^{105}$ The effect of such umbrella clauses is that a contractual obligation which the Ethiopian state entities owe to the investors from one of these countries, if not respected, will give rise to treaty claim. Investors whose basic treaty contains a general and broad MFN clause, but not an umbrella clause, may attempt to import the umbrella clause from any one of these comparator treaties. Even if the arbitral jurisprudence is not well settled, it still entails some level of uncertainty on the part of the host state.

Tribunals have also given effect to MFN clauses to overcome admissibility requirements (such as a requirement to submit disputes initially to local courts for an 18 month period). ${ }^{106}$ However, applying the MFN clause in those cases did not actually change the scope of the tribunal's jurisdiction agreed upon in the BITs or create 'consent' to arbitration that was otherwise lacking. It merely affected the timing of the host state's consent to, for example ICSID arbitration, and allowed tribunals promptly to hear claims over which they would later have jurisdiction in any event. ${ }^{107}$ The Gas Natural tribunal concluded that;

'...[u]nless it appears clearly that the state parties to a BIT or the parties to a particular investment agreement settled on a different method for resolution

${ }^{103}$ EDF International Award, paragraph 934. See also Id., p. 982.

${ }^{104}$ See Salini Costruttori S.p.A. and Italstrade S.p.A. and Italstrade S.p.A v. The Hasemite Kingdom of Jordan, ICSID Case No. ARB/02/13, Decision on Jurisdiction, 12 November 2004. See also Maupin, supra note 40, p. 170.

${ }^{105}$ Article $2 / 3$ of the Ethiopia-Denmark BIT and article $3 / 3$ of the Ethiopia-Kuwait BIT states: 'Each Contracting party shall observe any commitment it may have entered into with regard to investments of investors of the other contracting party.'

${ }^{106}$ Maffezini, Siemens, Camuzzi and Gas Natural.

${ }^{107}$ Freyer and Herlihy, supra note 39. 
of disputes that may arise, most-favored-nation provisions in BITs should be understood to be applicable to dispute settlement." 108

BITs are usually signed for a specified period of time. But their protection might extend to investments established prior to their entry into force based on the 'extension of temporal scope of application of arbitral clause'. Such BITs which extend their protection to investments established prior to the entry date, however, exclude from the coverage those disputes that have emerged before the entry into force of the BIT. For example, article 11 of the BIT between Ethiopia and China, states '...It shall, however, not be applicable to claims arising out of events which occurred prior to its entry into force.' In such circumstances, an MFN clause might be invoked to extend the temporal dimension of a basic treaty's dispute resolution provisions. ${ }^{109}$ In the case Tecmed versus Mexico, the claimant relied upon the basic Treaty's MFN clause to import into the basic treaty a retroactive application clause from a comparator treaty signed between Mexico and Austria. ${ }^{110}$ The tribunal, however, did not accept the claimant's request.

It is also important to note changes to arbitral forum or system of dispute resolution. This relates to a situation whereby a claimant would rely upon a comparator treaty in order to change the forum or displace the entire dispute resolution system selected by the basic treaty. ${ }^{111}$

\section{Some Observations of Arbitral Practice}

Generally, the arbitral practice highlights the importance of clearly delimiting the scope of application of the MFN clause in the text of these agreements. If contracting parties do not intend to extend MFN treatment to dispute settlement matters, it would be better for the investment agreement to explicitly say so. ${ }^{112}$ Accordingly, the general tenor of the arbitral jurisprudence is that MFN clauses allow for the incorporation of more favorable treatment concerning the admissibility of an investor-state claim, but do not allow investors to establish or to expand the jurisdictional basis for investor-State arbitration based on broader consent to arbitration in third-party BITs. ${ }^{113}$

Yet, the potential case towards a broader treaty interpretation is largely open in cases where the contracting parties have expressly stated that the MFN clause

${ }^{108}$ Gas Natural SDG, S.A. v. Argentine Republic, ICSID Case No. ARB/03/10, Decision on Jurisdiction, 2005.

${ }^{109}$ Maupin, supra note 40, p. 169.

${ }^{110}$ Tecmed vs. Mexico ... see also Ibid.

${ }^{111}$ Id., p. 171.

${ }^{112}$ UNCTAD, supra note 68, p. 53.

${ }^{113}$ Schill, supra note 29, p. 151. 
extends to dispute settlement provisions; absolving the need to inquire into their intent as the wording of the treaty is clear and must be given effect. ${ }^{114}$ In particular, the Plama Consortium Tribunal has announced what is considered to be a landmark test by commentators. Interestingly, while interpreting the requirement for consent to ICSID jurisdiction, the Tribunal stated: 'It is a wellestablished principle, both in domestic and international law, that such an agreement should be clear and unambiguous.' 115 The panel further stated: 'an MFN provision in a basic treaty does not incorporate by reference dispute settlement provisions in whole or in part set forth in another treaty, unless the MFN provision in the basic treaty leaves no doubt that the Contracting Parties intended to incorporate them. ${ }^{, 16}$ This implicitly commends that in cases whereby the terms of the treaty specifically incorporate treaty provisions addressing dispute settlement, there is a clear understanding of the intent of the parties to the BIT; it is assumed that they had consented to embed preferable terms of dispute settlement included under other BITs entered by one of the parties. $^{117}$

While Maffezini and Siemens favor the application of MFN status to dispute settlement, Salini and Plama say, at least in principle, the opposite, focusing on the intention of the parties as the decisive factor. In this view, reference to dispute settlement provisions from other treaties will be possible only where the parties to the BIT have a clear and unambiguous intention of incorporating it by the operation of the MFN clause. ${ }^{118}$ The same is true in the opposite scenario, where the parties have expressly excluded dispute settlement from the scope of an MFN clause, either through the wording of the original treaty or, for example, through a common Note of Interpretation.

Accordingly, commentators have already shown that the trend is essentially in this latter approach. As Gaillard notes:

'[T]he interpretation question of whether dispute settlement arrangements constitute a substantive right that can be extended to the beneficiary of an MFN clause arises when the clause is broadly phrased and the contracting parties to the treaty have neither expressly excluded dispute resolution mechanisms nor clarified their intention of including such mechanisms in the protection that is accorded to the beneficiaries of the clause. In those situations, the intention of the contracting parties can reasonably be interpreted to include the whole range of the rights accorded to the investors

\footnotetext{
${ }^{114}$ Maffezini v. Spain, Paragraph 52.

${ }_{115}$ Plama Consortium Limited v. Bulgaria, ICSID Case No.ARB/03/24, 2005, para 198.

${ }^{116}$ Ibid, para 223.

${ }^{117}$ Ibid.

${ }^{118}$ UNCTAD, supra note 77.
} 
of a third country, including the right to the neutral and effective settlement of their investment disputes through arbitration rather than through the judicial organs of the host state itself.' 119

A review of Ethiopian BITs indicate that in almost all of the BITs, the MFN clause is phrased in highly general terms and leaves considerable leverage to raise competing interpretations. In particular, most BITs are silent on whether by the MFN treatment they embrace only substantive rules for the protection of investments, such as guarantees of fair treatment as discussed above, or extend to other 'procedural protections' such as dispute settlement. Most of these BITs include general wording. The following two clauses from Article 3(2) of the Ethiopia-South Africa and Article 3(2) of Ethio-Germany BIT, respectively, illustrate this point with regard to the treatments of investments, national treatment and MFN treatment:

"Each Party shall in its territory accord to investments and returns of investors the other Party treatment as favorable as that which it accords to investments and returns of its own investors or to investments and returns of investors of any third State". ${ }^{20}$

"Neither Contracting Party shall subject investors of the other Contracting Party, as regards their activities such as the management, maintenance, use, enjoyment and disposal of their investments in its territory, to treatment less favorable than it accords to its own investors or to investors of any third State".

As discussed above, the implication of these terms is limited in terms of the possibility of including procedural protections via the MFN standard. The existing arbitral jurisprudence shows that tribunals are reluctant to apply such MFN treaty terms. However, there also exists an arbitral jurisprudence which shows the likelihood of broad applications of the MFN treatment if the treaty language shows an explicit intention of including the dispute settlement provisions of the BIT, like the one signed between Ethiopia and UK and Ethiopia and Belgian Luxembourg Economic Union. The implication of such an overtly stretched use of the MFN provision under the Agreements is that, an investor from the capital source state (in this case the UK) can potentially use the basic Ethiopia-UK BIT and shop for a more preferable dispute settlement

${ }^{119}$ Gaillard, supra note 71, p 3 Also see Emmanuel Gaillard, (2008), (in) Andrea K Bjorklund et al. (eds.) Investment Treaty Law: Current Issues III Remedies in International Investment Law The Emerging Jurisprudence of International Investment Law, (British Institute of International and Comparative Law), p 273.

120 Agreement between The Government of The Federal Democratic Republic of Ethiopia and The Government of The Republic of South Africa on the Promotion and Reciprocal Protection of Investments, signed on 1 January 2008. 
provision included in other BITs which Ethiopia has concluded now or will do so in the future with other states, hence potentially granting the investor the ultimate privilege for treaty and/or forum shopping.

\section{Concluding Remarks}

Countries sign BITs with the aim of attracting foreign direct investment and protecting the foreign investors' property from host State's actions. Ethiopia has signed 29 BITs with its trading partners. These BITs contain different standards of treatment, one of which is the Most Favored Nation treatment. This standard guarantees equality between investors of different countries with respect to competitive conditions. As discussed in the preceding sections, the dynamism in relation to the concept of Most Favored Nation treatment should be noted, in particular as raised in relation to the nature or purpose of MFN clauses and its interaction with dispute resolution provisions contained in the BITs. To this end, the different scenarios are examined whereby a foreign investor can possibly use BITs signed by Ethiopia, other than the investor's home state, to benefit from treaty obligations entered by Ethiopia with other partners - 'treaty shopping'.

A review of Ethiopian BITs indicate that in almost all of the BITs, the MFN clause is phrased in highly general terms and leaves considerable leverage to raise competing interpretations and creating a matrix of obligations with the effect of stretching the Country's obligations under the respective agreements. BITs are signed for a certain period of time. Many of the BITs Ethiopia signed have initial minimum period of 10 years while few extend beyond this timeframe. ${ }^{121}$ Depending on what is agreed, the BIT may allow for its automatic renewal for indefinite period of time subject to the right of the parties to terminate it at any time by giving notice of termination, known as 'any time termination clause'. ${ }^{122}$ Alternatively, the BIT may provide that it will continue to be in force for additional fixed period of time, in which case the treaty can be terminated only at the end of each fixed period. ${ }^{123}$

The fact that such clauses are inserted in the BITs gives the contracting parties the opportunity to revisit the BITs. The action taken by the South African and Indonesian governments can be taken as example. In September 2012, South Africa informed the Belgian-Luxembourg Economic Union, through a notice of termination, that it would not renew the existing BIT which was set to

${ }^{121}$ The initial minimum period contained in the BIT signed with Kuwait is for 30 years, with Finland 20 years, and with Russia 15 years.

${ }^{122}$ UNCTAD, supra note 13, p. 110.

${ }^{123}$ Ibid. 
expire in March 2013. ${ }^{124}$ The country also served a notice of termination in respect of its BIT with Spain on June 23, $2013^{125}$ and latter on to Germany, Switzerland and The Netherlands. ${ }^{126}$ The imprecise provisions contained in the old generation BITs which create uncertainty and unacceptable risk both to serious investors and the governments was stated as reason for the decision to terminate the BITs. ${ }^{127}$ Indonesia is also planning to terminate more than 60 BITs $^{128}$ and it has started giving notice of termination. A notice of termination was given to terminate the BIT with the Netherlands as of July 1, 2015. ${ }^{129}$ Some argue that this move is an attempt by the Indonesian government to update its BITs with a new model that reflects the latest legal technology as the older ones tend to contain provisions that protect foreign investors without specifically providing for the preservation of government's policy space to regulate in the public interest for health, the environment or for financial reasons. ${ }^{130}$

Many of the BITs signed by Ethiopia contain 'any time termination' clause, the ones signed with Kuwait being an exception. Considering the fact that many of these BITs entered into force in the early 2000, one can conclude that the initial minimum period of many of these BITs has lapsed or is about to lapse. This gives the government of Ethiopia a good opportunity to learn from the experience of other countries and revisit its BITs with the aim of having a coherent investment treaty framework.

${ }^{124}$ Id., p. 108. See also Publication by a spokesman of South Africa's Department of Trade and Industry, available at http://www.bdlive.co.za/ opinion/letters/2012/10/01/letter-critical-issues-ignored.

${ }^{125}$ Nicholas Peacock and Hannah Ambrose, South Africa terminates its BIT with Spain, available at $<$ http://www.lexology.com/library/detail.aspx?g=dar93855-71f9-425e92d3-5368d104f8ff $>$, [accessed on November 20, 2014].

${ }^{126}$ Robert Hunter, South Africa terminates Bilateral Investment Treaties with Germany, Netherlands and Switzerland, available at $<$ http://www/rh-arbitration.com $>$, [accessed on November 20, 2014].

$127<\mathrm{http} / /$ www.bdlive.co.za/ opinion/letters/2012/10/01/letter-critical-issues-ignored $>$, [accessed on November 20, 2014].

${ }^{128}$ Ben Bland and Shwan Donnan, Indonesia to Terminate more than 60 Bilateral Investment Treaties, Financial Times, March 26, 2014, online version available at $<$ http://www.ft.com>, [accessed on November 20, 2014].

${ }^{129}$ Simon Nesbitt et al, Indonesia terminates its Bilateral Investment Treaty with the Netherlands from 1 July 2015 and may terminate all of its BITs, available at $<$ http://www.lexology.com/library/detail.aspx?g=dar93855-71f9-425e-92d35368d104f8ff $>$ [accessed on November 20, 2014].

${ }^{130}$ Prof Michael Ewing-Chow and Mr Junianto James Losari, Indonesia is letting its Bilateral Treaties Lapse so as to Renegotiate Better ones, Financial Times, April 15, 2014, online version available at $<\mathrm{http}: / / \mathrm{www}$.ft.com $>$, [accessed on November 20, 2014]. 